DOI: 10.1515/auseur-2015-0003

\title{
National Traumas - Local Memories Villages Southeast and Southwest from Kolozsvár (Cluj-Napoca) during WW2 - General Research Overview
}

\author{
Alpár-Csaba NAGY \\ Babeş-Bolyai University, Cluj-Napoca \\ Faculty of Reformed Theology
}

\begin{abstract}
The presentation summarizes the results of two years of oral history research. The aim of the research was to record the recollections of the still living eyewitnesses of the events in the fall of 1944 in Cluj and its surroundings, in settlements that belonged to the southern part of Transylvania during World War II. Several hours of interviews were made in the villages of the regions of Tara Călatei (Kalotaszeg) and the Transylvanian Plain (Mezóség), and the lecture presents a synthesis of these interviews. They address issues like deportation, atrocities, fleeing, arm usage, Soviet and Romanian detention camps, adventurous escapes, etc.
\end{abstract}

Keywords: Transylvania, Romanians, Hungarians, ethnicity, WW2, traumas, injuries, requisition, interning, forced-labour camps

In April 2012, I had the chance to meet 'Bapóka bácsi' (Uncle Bapóka), the 85-year-old János Bükkös from the village of Aiton, Romania. The main goal of our meeting was not remembering the events of WW2, but - as the old man was personally affected - he shortly started storytelling about that period, and I found out the he was one of those who had been taken away from their homes like war criminals into concentration camps only because of their nationality, and that he was released two months later and got home in an adventurous way. Our discussion gave me the idea to start a research (for almost two years) in the scope of which I would ask in their last moments all those who are still alive from the generation that had suffered all these traumas. The Domus Hungarica fellowship of the Hungarian Academy, which I was granted for three years consecutively, made this research possible. 


\section{General Historical Overview}

In August 1940, the Romanian and Hungarian governments asked for the arbitration of the German and Italian governments in order to solve the territorial dispute between the two countries. The applicants obliged themselves to accept the terms of the decisions without reluctance. The arbitrary decision, which was made on the $30^{\text {th }}$ of August, 1940 in the Gold Cabinet of the Belvedere Palace in Vienna based on ethnic, economic, and strategic premises divided the land of Transylvania, which constituted the topic of the territorial debate, in two parts. The Northern part was annexed to Hungary and its southern part remained in Romania.

The new border torn Transylvania in two parts in an unprecedented way. It divided historical regions, centuries-old economic, social and cultural relationships, villages, families, doing all this without any pragmatic regard. Cities lost their supplier villages, industrial facilities their raw material bases, producers their markets, important railway lines became standoffs, main roads became dead ends. The decision parted Transylvania and its inhabitants. Romanians in north and Hungarians in south watched the new border sadly, with joy and acclamation on one side and rising hatred and nationalist hysteria on the other. The already burdened relationship of the two nations has turned to open animosity. Hundreds of Romanians were killed by the revenge of Hungarian paramilitary units in north, and hundreds of thousands of Hungarians were expecting their darkest period of minority existence in the south.

The events of the following four years led to the war of nerves because of the different conceptions of the two countries regarding the situation of minorities, and the way they were dealing with them, and because of the revisionist hopes emerging on both sides of the border, which evolved at the beginning into a cold war, but later, after King Michael's coup in 1944, it led to a state of war. The problem of Transylvania and the dispute of the two countries were definitively closed by the Romanian occupation of Northern Transylvania in 1944, the restoration of the Romanian administration, and the Peace Treaty of Paris in 1947.

During the four years of separation, the Hungarians of Southern Transylvania had to face the minority policy of the Antonescu regime. As I referred to it in my book (Nagy 2012), the approach of the Romanian government and public opinion toward the Hungarians was characterized in the researched period by serious hatred and revengefulness and the determination for ethnical cleansing. In the background of this approach were the following: the desire to avenge the injuries that the Romanians had suffered in Northern Transylvania; the determination to create the ethnically uniform Romanian nation-state; the politics based on reciprocity, which have been concretized in mutual avenge from both sides; the primitive nationalism, and finally pragmatic and economic considerations. And this approach did not change after August 1944. Even though it seems that 
Romania had come to an end with the fascist and nationalist ideology, which would implicitly mean that the xenophobia and ethnic cleansing should have become void in this period - at least officially. But it did not happen this way, and this is proved by a series of events that caused serious bitterness to the Hungarians of Romania.

The Hungarian-Romanian war, which broke out in September 1944, had several aspects. In Romanian circles, it was declared an antifascist war. The offensive started with the new ally, the Soviet Union, and it was officially against the alliance of the fascist Germany, Hungary and against fascism. But this war was considered also a national liberation war. Extremist Hungarian circles presented it as a means to punish the betrayal of Romanians and to liberate the Hungarian brethren from Southern Transylvania, while Romanians considered this war the liberation of Northern Transylvania invaded by the Hungarians. Hungarians in Transylvania became collectively guilty of fascism, and therefore they were the most feared enemy; so, they had to endure the retaliation for every injury suffered by the Romanians during WW2.

Therefore, the situation of the Hungarians became worse after 1944. They had to suffer because of discriminative laws; the trials of the court-martials started before 1944 did not cease, and new trials were to be expected. Hungarian people were forced into concentration camps, and these camps survived the war: half a year after the German capitulation, they were still inhabited by Hungarian prisoners. The injuries caused by the authorities were followed by injuries caused by the local Romanians. These were committed mostly in the villages near the border, especially in those which fell in the area of the offensive. There were such villages in which the authority was changed three times during a month. In these villages, the wealth of the Hungarian population and Hungarian churches were victims of the robbery of the soldiers and the revengeful civilians.

\section{General Description of the Research}

The border created by the Vienna Award was one lacking every strategic, economic, or ethnic consideration. It left in Romania those villages southeast and southwest from Cluj, inhabited mostly by Hungarians, which were connected with numerous economic and administrative links to the city like: Magyarfenes (in Romanian: Vlaha), Tordaszentlászló (Săvădisla), Magyarvalkó (Văleni), Györgyfalva (Gheorghieni), Ajton (Aiton), Kolozspata (Pata), Kiskályán (Căianu Mic), Mócs (Mociu), Magyarfráta (Frata), Mezőkeszü (Chesău), Magyarszovát (Suatu), Nagysármás (Sărmaşu), etc. A few of these villages were part of the legendary Goering-sack (the methane gas fields of the Transylvanian plain had to remain by Romania). 
The goal of the research was to visit these villages and to record interviews with the living witnesses of this period about everything they could tell about the suffered or heard injuries.

Historical sources testify a lot of personal injuries: emigration in order to avoid military service, interning in concentration camps, forced labour, robbing, physical injuries, and atrocities. My goal was to analyse their personal imprints. The analysed villages were border villages, and therefore they were exposed significantly both during the four-year division and during the war.

In my interviews, I analysed the following topics: anti-Hungarian injuries starting from the autumn of 1940 and their effects on the local communities, demographic and economic changes due to the second Vienna Award, the requisition of grain from the winter of 1942, the consequences of the RomanianHungarian war (looting, atrocities), interning in concentration camps, interning in forced-labour camps, retaliation from the local authorities, interethnic tensions, occasional clashes between the two communities, atrocities against people, identification of those persons who died due to the atrocities, the aftermath of the events and their later effects on the relationship of the communities.

I looked for people who were old enough during the events to be able to testify about them and still in adequate mental condition to be able to remember. Due to the advanced age of the subjects, their number was quite low (2-3 persons in a village), but there were also villages where I found only one person or none at all. Therefore, I created 39 interviews (20 hours of recordings, 670000 characters).

By a general overview of the interviews, I can definitely say that - as it was expected - from every experience those of personal humiliation were the ones that erupted the most significantly from the memories of my subjects. The interview with Mrs. Mária Császár is a good example. Even though she was only five and a half years old, she declared regarding the Soviet-Romanian offensive: 'I don't know what I ate yesterday, but I remember everything about how it was when the troops were retreating'. The stories told by Sándor Császár from Magyarfráta and by János Császár from Berkenyes (Berchieşu) are also very detailed: both of them told me about their internment to forced-labour camps in 1944. In the case of János Császár, it is very interesting that even though he considers himself Hungarian and he emphasized that he had been interned into forced-labour camp because he was a Hungarian, he still forgot his mother tongue and could speak only in Romanian. He cannot remember his mother tongue, yet he gave a detailed description of the events that happened to him in the labour camp of Buzău.

Traumas suffered by others or information gathered from third-hand sources were not recalled precisely, and the subjects often mixed events, places, or persons; so, these answers were often imprecise, short, vague, and reticent. It was frequent that events from the autumn of 1940 were confused with those from the autumn on 1944. For instance, Anna Szabó from the village of Novaj (Năoiu), 
near Pusztakamarás (Cămăraşu), recalled that Romanians in her village dressed in black because of their grief for the Vienna Award, but it turned out that they were grieving the occupation of their village by the Hungarian army in 1944 .

But later, when the recalled event was one the persons experienced themselves or they were the injured ones, the old people started to remember precisely whole dialogues, and the description of the events was detailed; they were often affected by their stories and told them with high emotional implication. Such implication was present in the narrative of Erzsébet Sinkó from Magyargyerómonostor (Mănăstireni), who was a little girl when the Romanian army invaded her village, or in that of István Lőrincz from Magyarvalkó (Văleni), who was lured in Soviet imprisonment with a simple trick, but when he recalled it, he shouted: 'The bastards!'

It is natural that in the perspective of time a lot of information lost its preciseness; such was the case of Dani Horváth from Mezőkeszü (Chesău), who was convinced that the requisition of grains had also affected the Romanian population of his village, while János Császár from Berkenyes (Berchieşu) stated that only the grain of the rich people had been seized.

I remarked that the subjects were familiar with the terminology of the historical events, they used naturally expressions like requisition (of grains), refugees (Romanians from Northern Transylvania), concentration, robot (the expression Soviet soldiers used to lure people to concentration camps), 'barysna' (Soviet soldiers were looking for girls to rape with this expression). I also have to remark that people from different areas and villages used the same expression when they spoke about different attitudes. The best example was 'mocking,' which expressed the attitude of Romanian authorities and civilians against Hungarians characterized by humiliation, verbal or physical aggression. In every village, the subjects recalled requisition as an event when Romanians 'scraped out even the troughs for flour' or when they 'swept' every bit of grain.

I also have to mention that during the grain requisition there were situations in every village when local Romanians acted humanely. Many Hungarian families were helped by their Romanian neighbours to avoid starving, and it was frequent that the authorities avoided to seize grain from poor or orphaned Hungarian families such as in the case of Mihály Járai from Pusztakamarás (Cămăraşu).

The judgement of the attitude of the Hungarian and German soldiers was often positive, but regarding the Germans there exists the grievance that they took away Hungarian men for workforce. They are recalled as soldiers who did not seize anything, yet they asked for food or other goods, and often paid for them, they were benevolent towards civilians, and often helped them (according to János Császár, they helped a local widow with many children).

Though the analysed territory was quite small, and included neighbouring villages, and even though the recalling of the general conditions and war events 
was similar, the narratives still contain a wide scale of personal injuries from humiliations to Soviet imprisonment, from interning to looting and from courtmartial trials to the death of close relatives.

\section{Results}

The interviews are oral testimonies of events that can be described through the historical sources. During the four and a half years of war, the following happened on the analysed territory:

The new border tore inorganically in two the historically consistent regions of Kalotaszeg (Țara Călatei) and Mezôség (Câmpia Transilvaniei), taking away their natural relationship with the centre, Kolozsvár (Cluj-Napoca). This was most relevant for Kolozspata (Pata), Györgyfalva (Gheorghieni), Magyarfenes (Vlaha), and Tordaszentlászló (Săvădisla) because these villages were in an organic relationship with the city. According to the witnesses, this rupture also affected the Romanian population as their main occupation was marketing. Since the traditional trade-route was closed by the border, the locals had no other chance than smuggling. And their businesses had to be arranged in the faraway Torda (Turda), connected with inferior roads. Therefore, these villages became centres for smugglers. The main goods transported to Hungary were lumber, soap, and raw food, and they brought garments and shoes in Romania. The closeness of Hungary increased the number of immigrants; almost every young person from these villages moved to Kolozsvár (Cluj-Napoca).

In the first years, peasants with land remained in the villages, but as Romania entered in the anti-Soviet war in 1941 Hungarian men were massively recruited in the Romanian army, and they all chose to immigrate rather than to become soldiers. Therefore, in the region, there are only a few war dead from the Romanian army, but a lot more from the Hungarian army. The heads of the families went for work, leaving their wives and children behind. Those who fled from recruitment also left their families behind, but they were exposed to the harassment of the authorities.

Since most of the villages were ethnically heterogeneous, the relationship between Romanians and Hungarians was strongly ambivalent: next to the conflicts implying violence, we may see clear evidence of benevolence too.

The memory of the 1942 grain requisition is still alive in every community. The memories they recall are pure witnessing of those contemporary reports we may read in archives from pastors and local political leaders. We have to emphasize that in every village Romanian neighbours helped the local Hungarians and showed clear signs of benevolence.

Though during these four years the ethnic-based atrocities, house searches against Hungarians were quite frequent, the subjects did not recall such events. 
This is probably because that type of official harassment involved mostly the intellectuals from the cities, while the peasants in villages were hit mostly by economic injuries. Still, the memory of ethnic harassment is living in the villages of Magyarszovát (Suatu) and Magyarfenes (Vlaha).

From the turn of 1944-45, subjects recalled three significant events: the entry of the Hungarian army for a short but memorable time, the later events of war regarding the looting of the Soviet-Romanian army and Romanian civilians, the atrocities against Hungarians, and finally the interning of the Hungarian men in concentration or forced-labour camps.

During the Romanian-Hungarian war, the Hungarian army occupied almost every village under analysis. Regarding these events, we have to remark a general sympathy towards the Hungarian 'honvéds' (soldiers). In several villages, the German troops took away civilians to help them carry their goods, and they followed the troops till the border of the Trianon Hungary.

The Soviet-Romanian offensive caused a lot of material damage and loss. We know that the soldiers looted the food reserves of the Hungarian population, they took away their livestock, their money, and small valuables. Soviet soldiers raped Hungarian girls, and in several cases escaping from the sexual harassment was a matter of coincidence. Many Hungarian soldiers were executed, and a lot of them died during the war events. The looting of the soldiers was followed by the looting of the civilians. Subjects recall that in the later times they found their furniture and valuables with Romanians from the neighbouring villages.

The retreat of the Hungarian-German troops caused a lot of damage in the infrastructure of the area. Roads, railroads, bridges, and tunnels became unusable, but to serve the logistics of the occupying Soviet-Romanian troops these had to be made usable. So, the Hungarian population of the nearby villages was taken to forced labour, and they were forced to work with their own tools and animals in the repairing operations.

But the greatest and most painful injury in every village was the interning of the Hungarian men in October 1944. There were three types of interned people: men who fled before the recruitment to the Romanian army and returned in their villages as retired Hungarian soldiers, families who went to work in Hungary and returned to their villages on the autumn of 1944, and those who remained permanently in their places but because of their ethnicity were taken to forced-labour camps. Regarding their destination, the prisoners had two categories: those taken to Romanian concentration camps and those taken to the Soviet Union. Personal narratives all relate inhumane circumstances, poor conditions, harassments, and even though most of the prisoners returned from the camps, a lot of them died during imprisonment. Subjects could not recall the names of those who died in the camps.

Interning was the consequence of the application of the elements of the armistice, which compelled Romania to intern every Hungarian and German 
citizen from its territory. But the selection of the interned people was made solely on ethnic considerations and not on citizenship because, as it seems, local authorities had to meet a certain quota regarding the number of the interned people. This way, even minor boys were taken to imprisonment, only because of their nationality.

The memory of the events of WW2 still determines the Romanian-Hungarian relationship in the area. These memories still live in the communities, and the compensation and the satisfaction for the suffered injuries is yet to come, not to mention the responsibility of the criminals. The subjects of harassment are not eligible even today for any financial compensation for their injuries.

\section{Conclusions}

The interviews with the subjects are valuable sources of the events from every village. Since military archives regarding the events are still not available for research, regarding several types of atrocities, these testimonies are the only evidence. Therefore, making these interviews is an urgent and important task. Due to the advanced age of the subjects, this work must be continued because these narratives show us the imprints of the events in the souls of people. They show us how they traumatized their lives, how they affected their ethnical identity and their relationship towards the Romanian community.

\section{References}

\section{Archive Sources}

Archives of the Southern Transylvanian Church District in the Archives of The Transylvanian Reformed Church of Kolozsvár (Cluj-Napoca).

\section{Literature}

BALOGH L. Béni. 2001. A magyar-román kapcsolatok 1939-1940-ben és a második bécsi döntés. Csíkszereda: Pro-Print.

BENKŐ Levente-PAPP Annamária. 2007. Magyar fogolysors a második világháborúban. Csíkszereda: Pallas-Akadémia.

GÁL Mária-BALOGH GAJDOS Attila-IMREH Ferenc. 1995. Fehér könyv az 1944. ószi magyarellenes atrocitásokról. Kolozsvár: RMDSZ.

ILLÉSFALVI Péter-SZABÓ Péter-SZÁMVÉBER Norbert. 2005. Erdély a hadak útján, 1940-1944. Budapest: Puedlo. 
NAGY Alpár-Csaba. 2012. A Dél-Erdélyi Református Egyházkerületi Rész története, 1940-1945. Budapest: L’Harmattan.

NAGY Mihály Zoltán-VINCZE Gábor (eds.). 2003. Autonomisták és centralisták. Észak-Erdély a két bevonulás között, 1944. szeptember-1945. március. Kolozsvár-Csíkszereda: Erdélyi Múzeum-Egyesület - Pro-Print Könyvkiadó. SÜTŐ András. 2011. Bertalan-éj a lelkünkön. In: Templomra szállt bánatmadár. Pusztakamarási magyarok. Kolozsvár: Kriterion.

SZENCZEI László. 1946. Magyar-román kérdés. Budapest: Officina.

\section{Studies}

BENKŐ Levente. 2003. A tervszerú merénylet. In: Korunk, February. 